\title{
Translational research targeting inflammatory responses and development of novel drugs
}

\author{
Masahiro Nishibori
}

Dept. Pharmacol., Okayama Univ. Grad. Sch. Med. Dent \& Pharmaceut Sci.

High mobility group box-1 (HMGB1) is a chromatin DNA-binding protein localized in nuclei. HMGB1, secreted or released from cells through cytosolic compartment by stress stimuli or injuries, exerts neurite outgrowth-promoting and pro-inflammatory activities. These features of HMGB1 on dynamics and biological activities are quite unique and distinct from those of known bioactive molecules. We raised anti-HMGB1 monoclonal antibody (mAb), validated the involvement of HMGB1 in different brain injuries and evaluated the efficacy of the mAb treatment. We found that the systemic injection of anti-HMGB1 mAb protected BBB disruption common to brain ischemia, hemorrhage, trauma and epilepsy, and reduced the inflammatory responses in the brain. We identified a plasma protein histidine-rich glycoprotein (HRG) as a HMGB1-binding protein. HRG plays a very important role in the homeostasis of blood cells, vascular endothelial cells and coagulation/fibrinolysis system. We proposed not only a novel hypothesis on septic cascade starting from a dramatic decrease in plasma HRG leading to immunothrombus formation but also a supplementary therapy with purified HRG. We identified CLEC1A as a novel receptor for HRG, and analyzed the regulation of HMGB1 mobilization by HRG. The translational research and drug development beginning with the target validation represent one of the directions in pharmacology.

High mobility group box-1（HMGB1）は、核内に局在するクロマチンDNA結合タンパクである。HMGB1はストレ 又刺激や細胞障害により、細胞質を経由して細胞外へ分泌・放出されると、神経突起伸展活性や起炎性活性を発揮 する。このような局在、動態、活性の特徵は、既存の活性物質群とは全く異なっている。演者は、HMGB1に対す る特異的単クローン抗体を作製し、抗体を用いて脳虚血、脳出血、脳外傷、てんかん等の中枢疾患におけるター ゲットバリデーションと治療効果の評価を行ってきた。その結果、抗体治療は、これらの傷害モデルで共通して観 察されるBBB破綻を強く抑制し、随伴する脳内炎症を軽減することで難治性脳疾患に治療効果を発揮することを明 らかにした。HMGB1結合因子として、血漿タンパクHRGを見出し、敗血症病態において血漿HRG低下を起点とす る病態形成の機序について新しい考え方と、HRG補充療法を具体的に提案した。HRGの新しい受容体として CLEC1Aを同定し、HMGB1動員のHRGによる制御を血管内皮細胞で解明した。ターゲット分子同定から開始する トランスレーショナルリサーチと創薬は、薬理学の一つの方向性を示す。 